\title{
Pengaruh Pemberian Bahan Aditif Berbeda terhadap pH dan Kandungan Bahan Kering Silase Sorgum Manis (Sorghum bicolor L.)
}

\author{
Mugfira $^{1)}$, B. Nohong ${ }^{2)}$, S. Nompo ${ }^{2}$, \\ 1) Mahasiswa Program Strata Satu Departemen Nutrisi dan Makanan Ternak, \\ Fakultas Peternakan, Universitas Hasanuddin. \\ 2) Dosen Program Strata Satu Departemen Nutrisi dan Makanan Ternak, Fakultas \\ Peternakan, Universitas Hasanuddin. \\ Email: Mugfirafhyfi@gmail.com
}

\begin{abstract}
Abstrak
Sorgum memiliki kemampuan untuk tumbuh baik disaat musim hujan maupun kemarau serta memiliki kandungan nutrisi yang hampir setara dengan rumput gajah. Hal ini tentunya dapat menjadi solusi dalam penyediaan pakan hijauan yang tidak kontinyu. Dalam pembuatan silase penambahan bahan aditif diperlukan untuk memperoleh hasil silase yang lebih baik. Penelitian ini bertujuan untuk mengetahui $\mathrm{pH}$ dan kandungan bahan kering silase sorgum manis yang diberi bahan aditif berbeda. Penelitian menggunakan rancangan acak lengkap (RAL) dengan 4 perlakuan dan 4 ulangan, yaitu P0: Kontrol, P1: Tepung Sagu 5\%, P2: Dedak Padi 5\%, dan P3: Dedak Jagung 5\%. Sampel dianalisis di Laboratorium untuk mengetahui $\mathrm{pH}$ dan bahan kering dari silase. Hasil penelitian menunjukkan bahwa $\mathrm{pH}$ silase sorgum pada perlakuan P0, P1, P2, dan P3 tidak berbeda nyata $(\mathrm{P}>0,05)$. $\mathrm{pH}$ dari silase sorgum yang dihasilkan berkisar antara 3,83 - 3,89 yang berarti merupakan silase dengan kualitas sangat baik. Sedangkan untuk kandungan bahan kering, silase pada perlakuan P0 (kontrol) sangat nyata lebih rendah $(\mathrm{P}<0,01)$ dibandingkan $\mathrm{P} 2$ dan nyata lebih rendah $(\mathrm{P}<0,05)$ terhadap $\mathrm{P} 1$ dan $\mathrm{P} 3$. Hal ini menunjukkan bahwa silase sorgum manis dengan $13 \%$ bx yang dibuat tanpa penambahan bahan aditif cukup layak untuk diterapkan melihat dari $\mathrm{pH}$ silase yang dihasilkan merupakan $\mathrm{pH}$ dengan kategori sangat baik.
\end{abstract}

Kata kunci: Bahan Kering, pH, Silase, dan Sorgum

\begin{abstract}
Sorghum has the ability to grow during the rainy and dry seasons and has a nutrient content that is almost equivalent to elephant grass. This certainly can be a solution in the provision of non-continuous forage feed. The addition of additives is needed when making silage to obtain better silage results. This study aims to determine the $\mathrm{pH}$ and dry matter content of sweet sorghum silage given different additives. The study used a completely randomized design (CRD) with 4 treatments and 4 replications, namely P0: Control, P1: Sago Flour 5\%, P2: Rice
\end{abstract}


Bran 5\%, and P3: Corn Bran 5\%. Samples were analyzed in the laboratory to determine the $\mathrm{pH}$ and dry matter of silage. The results showed that sorghum silage $\mathrm{pH}$ in treatments $\mathrm{P} 0, \mathrm{P} 1, \mathrm{P} 2$, and $\mathrm{P} 3$ were not significantly different $(\mathrm{P}>0,05)$. The $\mathrm{pH}$ of the produced sorghum silage ranged from 3,83-3,89 which means it is a silage with very good quality. As for the content of dry matter, silage in $\mathrm{P} 0$ (control) significantly lower $(\mathrm{P}<0.01)$ than $\mathrm{P} 2$ and significantly lower $(\mathrm{P}<0.05)$ than $\mathrm{P} 1$ and $\mathrm{P} 3$. This shows that sweet sorghum silage with $13 \%$ bx made without the addition of additives is quite feasible to apply, seeing that the $\mathrm{pH}$ of the resulting silage is a $\mathrm{pH}$ with a very good category.

Keywords: Dry Matter, pH, Silage, and Sorghum.

\section{PENDAHULUAN}

Sorgum merupakan salah satu jenis tanaman serealia yang mempunyai potensi besar untuk dikembangkan di Indonesia karena mempunyai daya adaptasi yang baik, toleran terhadap kekeringan dan genangan air, serta relatif tahan terhadap gangguan hama atau penyakit (Silalahi dkk., 2018). Sorgum dapat tumbuh dilahan kering, dan banyak berguna baik sebagai sumber bahan pangan, pakan ternak maupun bahan baku bermacam industri. Potensi sorgum untuk industri pakan (pengganti jagung) juga cukup tinggi (Nurharini, 2013).

Pemanfaatan tanaman sorgum sebagai pakan memiliki peluang yang sangat terbuka, sebab kandungan nutrisi pada batang dan daun sorgum hampir setara dengan rumput gajah yang sudah lebih dahulu populer sebagai bahan pakan ternak ruminansia (Irawan dan Sutrisna, 2011). Menurut Suarni dan Firmansyah (2016) kandungan nutrisi dasar sorgum adalah karbohidrat 70,7\%, lemak 3,1\%, protein $10,4 \%$, serat $2,0 \%$ dan kadar pati sorgum berkisar antara $56-73 \%$ dengan rata-rata 69,5\%. Pati sorgum terdiri atas amilosa (20-30\%) dan amilopektin (70$80 \%$ ), bergantung pada faktor genetik dan lingkungan.

Kandungan nutrisi sorgum yang baik, merupakan salah satu kelebihan tanaman ini untuk dijadikan pakan. Selain itu, sorgum memiliki kemampuan untuk tumbuh baik di saat musim hujan maupun kemarau. Hal ini tentunya dapat menjadi solusi atas permasalahan peternak dalam hal penyediaan pakan hijauan yang tidak kontinyu, dimana pada musim penghujan produksi hijauan melebihi kebutuhan dan pada musim kemarau produksi hijauan kurang dari kebutuhan (Malik, 2013). Menurut Syahrir dkk. (2013) agar pakan dapat tersedia secara berkelanjutan, perlu metode khusus untuk mengefisienkan penyimpanan pakan, 
tanpa mengurangi massa dan kualitas pakan, dan teknologi tepat guna yang aplikatif adalah pakan komplit berbentuk silase.

Silase merupakan teknik pengawetan pakan atau hijauan pada kadar air tertentu melalui proses fermentasi oleh bakteri yang berlangsung di dalam tempat yang disebut silo dengan tujuan untuk meningkatkan nilai gizi serta mengawetkan pakan (Haresta, 2017). Untuk mempercepat proses fermentasi, perlu ditambahkan zat atau bahan aditif dalam pembuatan silase. Menurut Stefani et al. (2010) macammacam aditif silase seperti water soluble carbohydrat, bakteri asam laktat, garam, enzim, dan asam. Dalam proses pembuatan silase, bahan tambahan sering digunakan dengan tujuan untuk meningkatkan atau mempertahankan kualitas dari silase (Kojo dkk., 2015).

\section{METODE PENELITIAN}

\section{Waktu dan Tempat Penelitian}

Penelitian ini dilaksanakan pada bulan Januari sampai Februari tahun 2019, di Lahan Pastura dan Laboratorium Kimia Pakan Fakultas Peternakan, Universitas Hasanuddin, Makassar.

\section{Materi Penelitian}

Alat yang digunakan dalam penelitian ini adalah kamera, parang, chopper, gunting, kantong plastik, tali raffia, lakban, label, timbangan, $\mathrm{pH}$ meter, amplop, alat cetak UMB dan peralatan untuk analisis bahan kering

Bahan hijauan yang digunakan dalam penelitian ini adalah tanaman sorgum yang berumur 80 hari dengan kandungan brix 13\%. Bahan aditif yang digunakan adalah tepung sagu, dedak padi, tepung jagung.

\section{Metode Pelaksanaan a. Rancangan penelitian}

Penelitian ini dirancang dengan menggunakan metode Rancangan Acak Lengkap (RAL) yang terdiri atas 4 perlakuan dan 4 ulangan, yaitu:

P0: Tanpa penambahan bahan aditif (kontrol)

P1: Penambahan tepung sagu 5\%

P2: Penambahan dedak padi $5 \%$

P3: Penambahan tepung jagung 5\% 


\section{b. Prosedur penelitian}

Tanaman sorgum yang telah berumur 80 hari dipanen kemudian dilayukan selama 3 jam hingga mencapai kadar air 70\%. Selanjutnya dicacah $\pm 3 \mathrm{~cm}$ menggunakan mesin chopper. Tujuan pencacahan adalah agar hijauan sorgum lebih mudah dipadatkan. Setiap satu plastik silo berisi 4,5 kg silase. Sorgum yang telah dicacah selanjutnya ditambahkan bahan aditif sesuai dengan perlakuan yaitu tanpa bahan aditif (P0), tepung sagu 5\% (P1), dedak padi 5\% (P2), dan dedak jagung 5\% (P3). Setelah itu, bahan atau hijauan silase dipadatkan sepadat mungkin hingga yang tersisa hanya udara yang ada diantara rongga hijauan. Plastik kemudian diikat dan dibungkus rapat untuk selanjutnya disimpan di tempat teduh selama 25 hari untuk proses fermentasi. Setelah 25 hari, silase yang telah jadi dibuka dan dipisahkan antara silase yang baik dan rusak. Tahap selanjutnya yaitu melakukan pengukuran berdasarkan parameter yang hendak diuji.

Pengukuran parameter dilakukan dengan cara mengukur $\mathrm{pH}$ silase yang telah dibuka menggunakan $\mathrm{pH}$ meter digital. Setelah itu mengambil sampel silase sebanyak 100 g untuk dimasukkan kedalam oven selama 24 jam untuk mengetahui kandungan bahan kering dari silase sorgum manis. c. Analisis data

Data yang diperoleh, dianalisis dengan menggunakan Rancangan Acak Lengkap (RAL) dengan 4 perlakuan dan 4 ulangan (Gaspersz, 1994) dengan model matematika sebagai berikut:

$$
\begin{array}{ll}
\qquad \mathrm{Y}_{\mathrm{ij}}=\mu+\pi_{\mathrm{i}}+\Sigma_{\mathrm{ij}} \text { Keterangan: } \\
\mathrm{Y}_{\mathrm{ij}} & =\text { Nilai Pengamatan dengan ulangan ke- } \mathrm{j} \\
\mu & =\text { Rata-rata umum (nilai tengah pengamatan }) \\
\pi_{\mathrm{i}} & =\text { Pengaruh perlakuan ke-I }(\mathrm{I}=1,2,3,4) \\
\Sigma_{\mathrm{ij}} & =\text { Galat percobaan dan perlakuan ke-I pada pengamatan ke-j }(\mathrm{j}=1,2,3,4)
\end{array}
$$




\section{HASIL DAN PEMBAHASAN}

Hasil analisis sidik ragam nilai $\mathrm{pH}$ dan kandungan bahan kering silase sorgum dapat dilihat pada Tabel 1.

Tabel 1 Hasil Pengukuran pH dan BK Silase Sorgum

\begin{tabular}{llc}
\hline \multirow{2}{*}{ Perlakuan } & \multicolumn{2}{c}{ Parameter } \\
\cline { 2 - 3 } & Nilai $\mathrm{pH}$ & $\mathrm{BK}(\%)$ \\
\hline P0 & $3,88 \pm 0,09$ & $23,00 \pm 0,82^{\mathrm{a}}$ \\
P1 & $3,85 \pm 0,06$ & $24,75 \pm 0,96^{\mathrm{b}}$ \\
P2 & $3,88 \pm 0,05$ & $27,75 \pm 1,26^{\mathrm{c}}$ \\
P3 & $3,83 \pm 0,09$ & $26,00 \pm 1,99^{\mathrm{b}}$ \\
\hline Keterangan: abc & Superskrip yang berbeda pada kolom yang sama menunjukkan pengaruh \\
\multicolumn{2}{c}{ nyata (P<0,05) dan sangat nyata (P<0,01). Hasil analisis Laboratorium Kimia Pakan } \\
\multicolumn{2}{c}{ Fakultas Peternakan Universitas Hasanuddin (2019). }
\end{tabular}

Hasil analisis ragam menunjukkan bahwa pemberian bahan aditif tidak memberikan pengaruh yang nyata $(\mathrm{P}>0,05)$ terhadap $\mathrm{pH}$ silase sorgum. $\mathrm{pH}$ pada perlakuan P3 atau silase dengan penambahan 5\% dedak jagung menunjukkan pH yang paling rendah dibandingkan perlakuan lainnya yaitu 3,83. pH yang dihasilkan dari seluruh perlakuan silase berkisar antara 3,83-3,88. Nilai tersebut menunjukkan bahwa silase yang dibuat memiliki kualitas yang sangat baik. Hal ini sesuai dengan pendapat Malik (2013) bahwa kualitas silase dibedakan menjadi

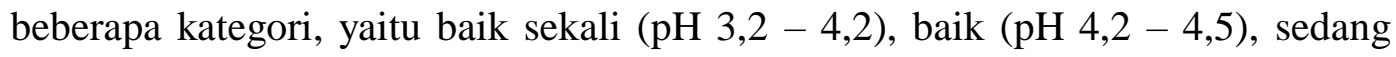
( $\mathrm{pH} 4,5-4,8)$, dan buruk $(\mathrm{pH}>4,8)$.

pH silase pada perlakuan tanpa bahan aditif $(\mathrm{P} 0)$ tidak berbeda nyata $(\mathrm{P}>0,05)$ dengan silase yang diberi bahan aditif (P1, P2, dan P3). Hal ini disebabkan tanaman sorgum yang digunakan mengandung brix (kadar gula) sekitar 13\%. Hal tersebut menyebabkan penurunan $\mathrm{pH}$ dapat tetap terjadi mengingat gula (karbohidrat) merupakan salah satu sumber makanan atau energi bagi bakteri asam laktat. Perry et al. (2003) menyatakan bahwa penambahan bahan kaya akan karbohidrat dapat mempercepat penurunan $\mathrm{pH}$ silase karena karbohidrat merupakan energi bagi bakteri pembentuk asam laktat.

Despal et al. (2011) menyatakan bahwa penambahan water soluble carbohydrates akan meningkatkan fermentable carbohydrate silase yang menyediakan lingkungan yang baik bagi berkembangnya bakteri untuk 
memproduksi asam laktat serta penurunan $\mathrm{pH}$ silase. Penambahan bahan aditif untuk proses ensilase sering digunakan untuk memperbaiki kualitas silase. Penambahan sumber water soluble carbohydrates menyebakan produksi asam laktat yang cukup untuk menurunkan $\mathrm{pH}$ dan memperbaiki kualitas silase (Bureenok et al., 2005).

Hasil analisis sidik ragam menunjukkan bahwa pemberian bahan aditif memberikan hasil kandungan bahan kering (BK) yang berbeda sangat nyata $(\mathrm{P}<0,01)$ dan nyata $(\mathrm{P}<0,05)$ terhadap silase sorgum. Uji Duncan menunjukkan bahwa perlakuan $\mathrm{P} 0$ sangat nyata lebih rendah $(\mathrm{P}<0,01)$ dibandingkan dengan perlakuan $\mathrm{P} 2$ dan nyata lebih rendah $(\mathrm{P}<0,05)$ terhadap perlakuan $\mathrm{P} 1$ dan $\mathrm{P} 3$. Adapun pada perlakuan P1 dan P3 nyata lebih rendah $(\mathrm{P}<0,05)$ dibandingkan perlakuan P2, sedangkan antara perlakuan P1 dan P3 tidak berbeda nyata $(\mathrm{P}>0,05)$. Kandungan $\mathrm{BK}$ secara berurut dari yang paling rendah sampai yang paling tinggi adalah P0 (24,00\%), P1 (25,75\%), P3 (27,00\%) dan P2 (28,75\%).

Data pada Tabel 2 menunjukkan bahwa perlakuan P0 (tanpa bahan aditif) memiliki BK terendah, hal ini disebabkan karena kurangnya sumber energi bagi bakteri asam laktat yang menyebabkan fase anaerob berlangsung lebih lama dibanding perlakuan lain sehingga menghasilkan panas, $\mathrm{CO}_{2}$ dan $\mathrm{H}_{2} \mathrm{O}$. Peningkatan kadar $\mathrm{H}_{2} \mathrm{O}$ selama ensilase akan menyebabkan kandungan bakan kering pada silase menurun sehingga menyebabkan peningkatan kehilangan bahan kering (Surono dan Budhi, 2006). Riswandi (2014) bila sumber energi yang digunakan oleh mikroba hanya berasal dari hijauan, mikroba akan memecah komponen bahan makanan dari hijauan sehingga menyebabkan kandungan bahan kering menjadi rendah.

Peningkatan kandungan BK tertinggi pada perlakuan P2 dapat disebabkan oleh penggunaan bahan aditif (dedak padi) dalam pembuatan silase. Hasil penelitian Santi dkk. (2012) menyatakan bahwa peningkatan level akselerator memacu aktifitas fermentasi sehingga produksi $\mathrm{H}_{2} \mathrm{O}$ menurun dan kandungan $\mathrm{BK}$ meningkat. Sawen dkk. (2003) melaporkan bahwa, dedak padi yang diberikan ke dalam silase menambah kandungan bahan kering silase menjadi lebih tinggi antara 26,93\% - 34,42\%. Hasil penelitian Riswandi (2014) menunjukkan bahwa kandungan bahan kering silase yang ditambahkan dedak halus 2,5\% dan ubi kayu 
2,5\% menghasilkan kandungan bahan kering silase tertinggi yaitu sebesar 13,43\%.

Kandungan BK merupakan aspek penting dalam penentuan kualitas silase.

Bahan segar atau hijauan sorgum yang digunakan dalam penelitian memiliki kandungan BK 30\%. Dari data pada Tabel 2 diketahui bahwa pebuatan pakan fermentasi berupa silase menurunkan kandungan BK dan meningkatkan kadar air silase. Menurut Hu et al. (2009) silase berkualitas baik mengandung kadar air sebesar $67 \%$ dan dalam kondisi ini pertumbuhan Clostridia sudah dapat ditekan.

\section{KESIMPULAN}

Berdasarkan hasil penelitian silase sorgum, dapat disipulkan bahwa:

1. Perlakuan tanpa penambahan bahan aditif maupun dengan penambahan bahan aditif memiliki $\mathrm{pH}$ berkisar 3,83 - 3,88. Untuk itu, pengaplikasian silase sorgum manis dengan kandungan $13 \%$ bx, tanpa bahan aditif cukup layak untuk diterapkan melihat dari $\mathrm{pH}$ yang dimiliki merupakan kategori silase dengan kualitas sangat baik.

2. Kandungan BK silase secara berurut dari yang paling rendah sampai yang paling tinggi adalah P0 (24,00\%), P1 (25,75\%), P3 (27,00\%) dan P2 (28,75\%).

\section{DAFTAR PUSTAKA}

Bureenok, S., T. Namihira, M. Tamaki, S. Mizumachi, Y. Kawamoto, and T. Nakada. 2005. Fermentative quality of guineagrass by using fermented juice of the epiphytic lactic acid bacteria (FJLB) as a silage additive. Asian-Aust. J. Anim. Sci. 18:807-811.

Despal, I.G. Permana, S.N. Safarina, and A.J. Tatra. 2011. Addition of water soluble carbohydrate sources prior to ensilage for ramie leaves silage qualities improvement. Med. Pet. 34: 69-76.

Gaspersz, V. 1994. Metode Rancangan Percobaan untuk Ilmu-ilmu Pertanian, Teknik dan Biologi. Bandung: CV Armico. 472.

Haresta, J. 2017. Produksi Biomassa dan Silase Beberapa Genotipe Sorgum (Sorghum bicolor (L.) Moench) yang Ditanam Secara Tumpangsari dengan Ubikayu pada Dua Lokasi Berbeda. Skripsi. Universitas Lampung, Bandar Lampung.

Hu, E., R.J. Schmidt, E.E. McDonell, C.M. Klingerman, and L. Kung Jr. 2009. The Effect of Lactobacillus buchneri 40788 or Lactobacillus plantarum 
MTD-1 on the Fermentation and Aerobic Stability of Corn Silage Ensiled at Two Dry Matter Cortents. J. Dairy Sci. 92: 3907-3914.

Irawan, B., N. Sutrisna. 2011. Prospek pengembangan sorgum di Jawa Barat mendukung diversivikasi pangan. Forum Penelitian Agro Ekonomi. 29(2): 99-113.

Kojo, R.M., Rustandi, Y.R.L. Tulung, dan S.S. Malalantang. 2015. Pengaruh penambahan dedak padi dan tepung jagung terhadap kualitas fisik silase rumput gajah (Pennisetum purpureumcv). Jurnal Zootec. 35(1): 21-29.

Malik, M.A. 2013. Kualitas Fisik dan Kimiawi Silase Tanaman Sorgum Manis (Sorghum bicolor L. Moench) Umur 70 Hari dengan Penambahan Aditif. Skripsi. Institut Pertanian Bogor, Bogor.

Nurharini, A. I. 2013. Pengaruh Waktu Panen Batang Sorgum Manis (Sorghum bicolor (L) Moench) terhadap Nira yang Dihasilkan. Skripsi. Universitas Hasanuddin, Makassar.

Perry, E., J.E. Oldfield, and W.W. Heinemann. 2003. Feeds and nutrition. 2nd Edition. California: The Ensminger Publishing Company.

Riswandi.2014. Kualitas Silase Eceng Gondok (Eichornia crassipers) dengan Penambahan Dedak Halus dan Ubi Kayu. Jurnal Peternakan Sriwijaya. 3(1).

Santi, R.K., D. Fatmasari, S.D. Widyawati dan W.P.S. Suprayogi. 2012. Kualitas dan Nilai Kecernaan InVitro Silase Batang Pisang (Musa paradisiaca) dengan Penambahan Beberapa akselerator. Journal Tropical Animal Husbandry. 1(1): 15-23.

Sawen, D., O. Yoku, dan M. Junaidi. 2003. Kualitas Silase Rumput Irian (Sorgum $s p$ ) dengan Perlakuan Penambahan Dedak Padi pada Berbagai Tingkat Produksi Bahan Kering. Seminar Nasional Teknologi Peternakan dan Veteriner. Fakultas Peternakan Perikanan dan Ilmu Kelautan Universitas Negeri Papua, Monokwari.

Silalahi, M.J., A. Rumambi, M.M. Telleng, W.B. Kaunang. 2018. Pengaruh pemberian pupuk kandang ayam terhadap pertumbuhan tanaman sorgum sebagai pakan. Zootec. 38(2) :286-295.

Stefani, J.W.H., F. Driehuis, J.C. Gottschal, and S.F. Spoelstra. 2010. Silage fermentation processes and their manipulation: Electronic Conference on Tropical Silage. FAO: 6-33.

Suarni dan I.U. Firmansyah. 2016. Struktur, Komposisi Nutrisi dan Teknologi Pengolahan Sorgum. Inovasi Teknologi dan Pengembangan. Balai Penelitian Tanaman Serealia.

Surono, M.S., dan S.P.S. Budhi. 2006. Kehilangan Bahan Kering dan Bahan Organik Silase Rumput Gajah pada Umur Potong dan Level Aditif yang Berbeda. Journal Indonesia Tropical Animal Agricultur. 31(1): 62-67.

Syahrir, S., M.Z. Mide dan Harfiah. 2013. Evaluasi Fisik Ransum Lengkap Berbentuk Wafer Berbahan Bahan Utama Jerami Jagung dan Biomassa 
Mugfira, B. Nohong, S. Nompo / Buletin Nutrisi dan Makanan Ternak 13(1): 26- 33

Murbei. Proseding Seminar Nasional dan Forum Komunikasi Industri Peternakan. Bogor, 18-19 September 2013. 